\title{
RACHAR E DESPENCAR O CORPO-TERRITÓRIO
}

Eduardo Oliveira Miranda ${ }^{\mathrm{i}}$

Resumo: O presente texto tem a sua tessitura a partir de provocações sobre a constituição do corpo-território (MIRANDA, 2014; 2019) do autor e como o ato de pesquisar tem sido uma das ramificações das colonialidades dentro da universidade. Para tal, inicia-se o texto com as provocações sobre as potências, imanências, lacunas e possibilidades do corpo no campo social e da educação. Nesse cenário, o autor mescla uma narrativa da sua experiência no trânsito pelo doutorado e a descoberta do dispositivo metodológico denominado de Sociopoética (GAUTHIER, 2014), a qual se estrutura em cinco princípios e exige um fazer ciência de corpo todo. Portanto, o autor deste texto sentiu a necessidade de ser atravessado pela Sociopoética e participou de um PERCURSO. Em seguida traz uma proposição decolonial batizada de Encruzilhada do Desenho Singular.

Palavras-chave: Corpo-território; Sociopoética; Rachar; Despencar.

\section{AGRIETAR Y DISPENSAR EL TERRITORIO DEL CUERPO}

Resumen: El presente texto parte de provocaciones sobre la constitución del cuerpo-territorio del autor (MIRANDA, 2014; 2019) y cómo el acto de investigar ha sido una de las ramificaciones de las colonialidades dentro de la universidad. Para ello, el texto parte de las provocaciones sobre los poderes, inmanencias, brechas y posibilidades del cuerpo en los campos social y educativo. En este escenario, el autor mezcla una narrativa de su experiencia en tránsito por el doctorado y el descubrimiento del dispositivo metodológico denominado Sociopoética (GAUTHIER, 2014), que se estructura en cinco principios y requiere hacer ciencia corporal. Por ello, el autor de este texto sintió la necesidad de ser atravesado por la Sociopoética y participó en una RUTA. Luego trae una propuesta descolonial llamada Singular Design Crossroads.

Palabras clave: Cuerpo-territorio; Sociopoética; Romper; Plomada.

\section{Rachar e despencar: primeiras trocas}

\author{
Rachar e despencar \\ Corpo теи \\ Tem deixado de ser \\ Por oras dono da razão \\ Não sei se ele ganha \\ Afirmo que ele perde? \\ Adormece ou anestesia-se?
}


Olha com as mãos

Cheira com os olhos

Degusta com as narinas

Compreende com o paladar

Dança com o corpo alheio

Se impõe, mas cede

Exige, mas entrega

Fala escutando

Escuta falando

Cartografa epistemes

E não temes se rachar

Se quebra para ampliar

O que sobrou?

Porquê devo te contar?

O mais gostoso é se despencar

Fonte: arquivo pessoal

Meu corpo, seu corpo, nossas corpas merecem uma conceituação ou cabem no campo da experimentação? Conceituá-lo restringe suas possibilidades? Experimentá-lo é uma via para a libertação? Se o corpo é um constructo sócio-bio-cultural, então podemos transgredi-lo ao campo do inimaginável? São infinitas as interpelações que não cabem em uma mera dissertação, em um ensaio ou muito menos neste artigo de provocações.

Para tensionar ainda mais estes caminhos, resolvi iniciar nossos diálogos com o poema, de minha autoria, Rachar e Despencar, duas expressões que sempre vêm a minha mente quando me questionam o que é a Sociopoética. Por isso, o poema inicial aparece neste momento para apresentar ao leitor(a) deste artigo como se deu o primeiro contato com a Sociopoética e de que forma esta perspectiva filosófica contribuiu para repensar a minha condição de educador, o que recai nos tensionamentos do meu próprio corpo-território que "é um texto vivo, um texto-corpo que narra as histórias e as experiências que o atravessa" (MIRANDA, 2019, p. 17). Portanto, ao escrever o poema que abre esta produção textual, busco compartilhar com a leitora uma experiência que atravessou o meu corpo-território, bagunçou as subjetividades, trocou de pele e alcançou uma outra corporeidade.

Não basta escrever que o meu corpo é um texto vivo se nas oportunidades de socialização negligencio o que me des-a-feta. Só posso rachar e despencar se a vivacidade da Revista Interinstitucional Artes de Educar. Rio de Janeiro, V. 7, N. 1 - pág. 467-487 janeiroabril de 2021: "Pedagogias Vitais: Corpo, Desejo e Educação" DOI: 10.12957/riae.2021.54972 
minha existência for provocada e, ninguém se constrói sozinho, nenhum corpo-território está livre das disputas de poder sobre sua própria espiritualidade.

Neste compasso, rachar e despencar, sobretudo na Educação, na sala de aula, nos espaços institucionalizados, significa uma desobediência epistêmica, uma ruptura linear da padronização, um rasteira em ideologias que te falam o que pode, e o que não pode, nosso corpo-território. Se o capitalismo busca a obediência, estamos aqui para propor uma circularidade que devolve ao sistema neoliberal uma educação da boçalidade-ladina. Com Muniz Sodré (1983) aprendi que corpo-território boçal é aquele que desaponta, incomoda e recebe insultos da branquitude. Já com Lélia Gonzalez (1988) o ensinamento é sobre a nossa condição de sujeitos ladinos, adjetivados pela elite branca, os quais fogem da regra e que por conta dessa rebeldia são desviantes e espertinhos. Sejamos, então, corpo-território-boçalladino que reinventa a Educação para movimentos contra-hegemônicos e pela libertação dos corpos subalternizados.

$\mathrm{O}$ ato de rachar e despencar provocado pela Sociopoética urge em questionar as potencialidades humanas da criatividade, as quais estão "adormecidas, esterilizadas na vida ordinária" (GAUTHIER, 1999, p. 14). É justamente esse processo de anestesia que deve ser banido da Educação. Não dá mais para reproduzir a ideologia de que a escola deve nutrir o controle dos corpos, o soterramento das afetividades e em muitos casos a universalização das sensibilidades. Qualquer espaço de poder que se vale das colonialidades para continuar a existir, exemplo da própria escola, o faz a partir de um pacto fetichista da violência subjetiva aliada às edificações do concreto universal das civilizações colonizadoras. Em outras palavras, o campo da Educação tem sido uma protoforma para legitimar a estrutura social pautada na identidade e no posicionamento político do heteropatriarcado cristão, branco e capitalista. No caso brasileiro, este cenário é facilmente identificado com duas intencionalidades conservadoras: Escola Sem Partido ${ }^{\text {ii. }}$ Ideologia de Gênero ${ }^{\text {iii }}$.

Portanto, visualizei na Sociopoética a possibilidade de contrapor o lugar do corpoterritório no âmbito das pesquisas acadêmicas e ao mesmo tempo descortinar a passividade criativa dos copesquisadores $^{\text {iv }}$. Então, por acreditar na formação docente com a emergência da interculturalidade, desenhei as interconexões dos postulados de Santos (2002) com os princípios da Sociopoética (GAUTHIER, 2014). Escolher o texto "para uma sociologia das ausências e uma sociologia das emergências" de Santos (2002) se deu pelo fato de o educador português construir um enredo textual representativo das condições sociais, políticas, econômicas, educacionais e culturais que afirmam a hierarquização dos saberes e, 
em muitos casos, a expurgação de toda a forma de ser, pensar e viver o mundo que não esteja de acordo com o padrão da Razão Indolente:

A razão indolente subjaz, nas suas várias formas, ao conhecimento hegemônico, tanto filosófico como científico, produzido no Ocidente nos últimos duzentos anos. A consolidação do Estado liberal na Europa e na América do Norte, as revoluções industriais e o desenvolvimento capitalista, o colonialismo e o imperialismo, constituíram o contexto sócio-político em que a razão indolente se desenvolveu (SANTOS, 2002, p. 40).

Pensar a razão indolente na escola, na universidade e na constituição da docência invoca tais questionamentos: como me constituir professor que não reproduza a Razão Indolente? É válido manter um currículo escolar que cotidianamente reproduz a Razão Indolente? Por qual motivo ainda continuamos a desperdiçar tantas experiências?

Nas cruzadas coloniais o corpo docente sempre se insere como o alvo preferido das fogueiras antidemocráticas. A indolência é fogo que arde com o respaldo da raiva, violências, certezas absolutas de que a colonização se converteu em colonialidades responsáveis por adestrar as corporalidades subalternizadas. Contudo, as caravelas continuam a subestimar as ocultas potências dos corpos-territórios insurgentes, os quais se aquilombam para provocar, em outros corpos-territórios, o Rachar e Despencar. No meu caso, em particular, chego ao doutoramento em Educação com muitas incertezas de como construir/criar/inventar os elementos da minha tese. Após uma longa busca por abordagens metodológicas descubro a Sociopoética. Amor à primeira leitura, aos primeiros artigos lidos, aos direcionamentos fora da linearidade cartesiana e, sobretudo, um outro ritual para perspectivar o corpo dos subalternizados enquanto produtores de ciência.

Porém, não conseguia me autorizar em utilizar a Sociopoética na tessitura da minha tese de doutoramento. $\mathrm{O}$ meu corpo-território não se sentia legitimado pela cachaça ritualista presente nos diversos textos que li, fichei, degustei e socializei. Sentia falta de sentir de corpo todo uma experiência de-formativa com a Sociopoética. Por conta disso, resolvi articular um encontro presencial, sob a mediação da pesquisadora Shara Adad, uma das socializadoras da Sociopoética, intitulado PERCURSO (Pesquisa + Curso) de formação em Sociopoética. Assumo o compromisso de expor neste artigo a referida atividade por compreender que se faz de extrema urgência a socialização dos princípios da Sociopoética, bem como das experiências por mim vividas atravessaram a minha corporeidade e possibilitaram a criação de outras perspectivas de vida e atuação profissional. 


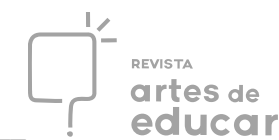

A aproximação com a Sociopoética se deu pela leitura do livro Tudo que não inventamos é falso, no qual fui apresentado a uma série de artigos com relatos da aplicabilidade desse recurso filosófico e prático que teve bases fundadoras nas pesquisas do professor Jaques Gauthier. Após a leitura de algumas páginas deparei-me com o artigo $A$ Sociopoética e os cinco princípios: a filosofia dos corpos misturados na pesquisa em educação, de autoria da educadora Shara Adad. Abaixo proponho, trago uma correlação entre o de Adad (2014) com a Razão Indolente indicada por Santos (2002), com o intuito de apresentar os 5 princípios constitutivos da Sociopoética. Nestes veios, a leitora será convidada a compreender e acessar como o meu corpo-território devorou, sentiu, des-a-fetou e perspectivou um fazer científico.

\section{Pesquisar entre as pessoas de um grupo}

No primeiro princípio percebe-se forte influência das contribuições de Paulo Freire no trato com os atores e atrizes da pesquisa, os quais são convidados a participar de todo o processo, ou melhor, sem as suas intervenções e contribuições não existe pesquisa, posto que são alçados à condição de copesquisadores e copesquisadoras. A inserção desses sujeitos é que legitima o processo metodológico. "Nesse sentido, pesquisar entre pessoas de um grupo é propiciar o aflorar das dúvidas, do pensamento e das questões dos próprios copesquisadores e experienciar, por meio das oficinas, o gozo de ser bando" (ADAD, 2014, p. 45).

Essa partilha, entre as envolvidas, me faz acreditar na possibilidade de diálogos respeitosos, movimentos de se ver e se colocar no lugar do outro e no retorno desse deslocamento, consubstanciado pela alteridade (Fig. 1), efervescer uma reflexão intersubjetiva de corpo inteiro, pois "pensamos através de outros, enquanto outros pensam em nós. Isso é arte, uma vez que esse pensamento, apesar de coletivo, expressa singularidades irredutíveis a um padrão, uma norma social" (GAUTHIER, 1999, p. 23). 


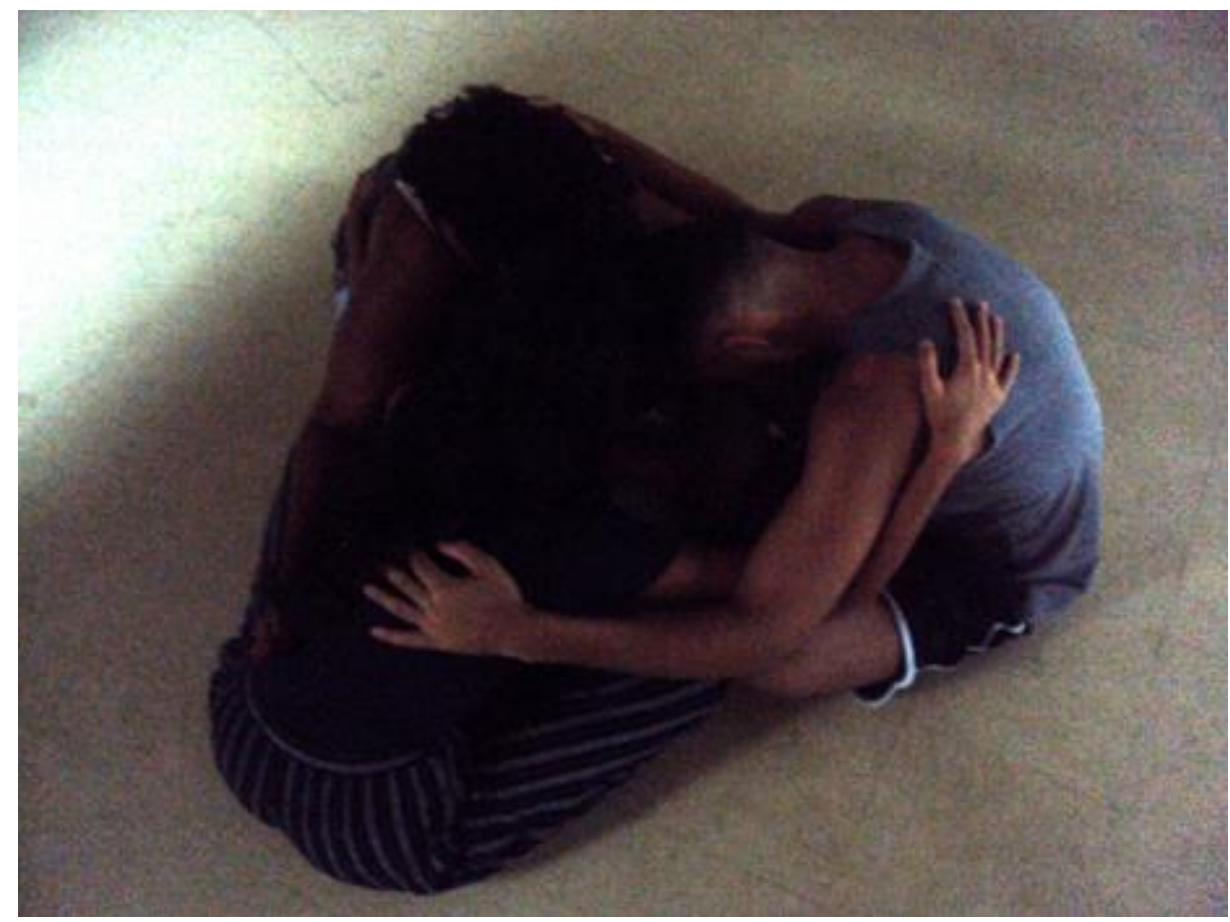

Figura 1: Preparação do grupo para o PERCURSO. Fonte: Arquivo Pessoal, 2018.

O primeiro princípio contraria a Razão Indolente, pois não se estabelece a norma de hierarquia entre os corpos-territórios, já que todos os envolvidos são convidados a participar igualmente na produção de conhecimentos, pois "tocar o corpo da outra pessoa, sentir a sua respiração, o seu cheiro, a intensidade das suas gestualidades faz com que aguce a minha vontade em respeitar o tempo do outro" (Diário das Trocas de Peles, 2018) ${ }^{\mathrm{v}}$.

Sendo assim, compreendemos que os envolvidos no PERCURSO, em consonância com o primeiro princípio da Sociopoética, são considerados copesquisadores, visto que passaram a ser compreendidos como "parceiros e parceiras dos facilitadores da pesquisa, tanto na construção do conhecimento como nas decisões que se deve tomar para que o próprio processo de pesquisa chegue até sua conclusão" (GAUTHIER, 1999, p. 41).

Para algumas pessoas deve soar como algo irrisório o fato de sentar com pessoas desconhecidas e atender alguns comandos de uma pesquisadora facilitadora. Contudo, garanto, de corpo todo, que a figura 1 retrata um dos caminhos fundantes para o Rachar $e$ Despencar. Posto que nosso corpo-território é criado por disputas de poder, deixar sentir o toque do outro é justamente o momento no qual se evidencia nossa posse sobre nosso território subjetivo. A mão de uma outra pessoa, desconhecida, consegue constranger, criar um desconforto: liga-se um sistema de alerta. Isso é imprescindível para criar uma instabilidade inicial, mas que com acordos e permissões levam o grupo a sentir a confiança entre os corpos-territórios. 
Romper o receio do toque de outro corpo-território é o abrir para Rachar e Despencar por conseguir fissurar a concepção eurocêntrica de que "penso, logo existo". Ou seja, experimentar o meu corpo-gay com outras corporalidades, sejam elas LGBT+ ou heterossexuais, só é possível ao trazer a ideia de que existo, logo penso. Para a colonialidade, um corpo não heterossexual, um corpo-gay, desviante da norma, é categorizado o outro do padrão. Portanto, o primeiro princípio da Sociopoética só pode ser constituído por pessoas que enxergam no outro corpo-território a sua condição humana, a qual carrega seus marcadores sociais, raciais, de gênero e sexualidades como condição de existência e não como fator de hierarquização.

\section{Pesquisar com as culturas de resistência, das categorias e dos conceitos que produzem.}

A terminologia "resistir", no contexto brasileiro, apresenta diversas aplicabilidades nas variadas esferas étnicas, culturais, de gênero, entre tantas outras questões que são silenciadas, negligenciadas, dicotomizadas e inferiorizadas pela razão indolente. É justamente a dicotomia hierarquizada que a Sociopoética, sobretudo no segundo princípio, tenta desconstruir.

Em relação ao trato com a diversidade de cosmovisões, construímos durante a passagem pelo PERCURSO um corpo batizado de Ventania (Fig. 2), o qual teve como objetivo geral reforçar os grupos de resistência com ênfase na potência democrática de Iansã. $\mathrm{O}$ ato de criar o corpo Ventania não partiu da combinação de ideias entre os envolvidos na formação, muito pelo contrário, a junção dos elementos aconteceu sem hierarquias e sem acordos estéticos. Mais uma questão comum uniu os corpos dos responsáveis pela invenção de Ventania: autor e autoras marcados por questões sociais que exigem um olhar aguçado para as opressões. 


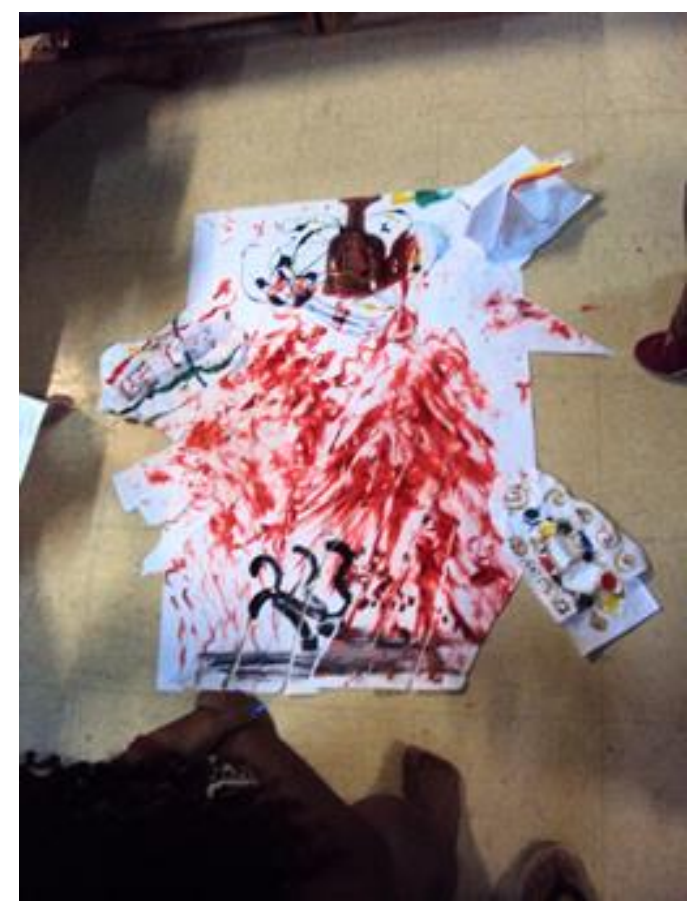

Figura 2: Corpo Ventania criado no PERCURSO. Fonte: Arquivo Pessoal, 2018.

É inquestionável que a sociedade é composta por questões dicotômicas, mas essas não devem ser padronizadas, igualadas ou simplesmente soterradas vivas com organismos culturais pulsando pela resistência. Destarte, ao criar Ventania procuramos levar em conta a prerrogativa de decolonizar as ideologias, os currículos educacionais, as metodologias e epistemologias de pesquisas, enfim, uma série de fatores que cotidianamente são utilizados para perpetuar a linearidade do tempo ocidental, denominada por Boaventura de razão proléptica $^{v i}$, bem como o descarte irresponsável de saberes e experiências legítimas e representativas de distintos contextos socioculturais. É justamente esse desperdício que motiva o nosso desejo em "encontrar o que foi silenciado, aquele saber de raízes que dorme na terra do povo e, às vezes, brota ou explode em rebentos novos" (GAUTHIER, 1999, p. $33)$.

\section{Pesquisar com o corpo todo}

Seria o corpo apenas o biológico/genético? Seria o corpo referenciado simplesmente por motricidade e deslocamento? Ou poderíamos entendê-lo a partir da perspectiva racionalista que separa corpo e mente? São diversos os questionamentos que nos 
acompanham sempre que o termo/categoria Corpo é empregado no campo das ciências humanas.

Tais interpelações foram e continuam a ser apregoadas em diversas literaturas academicistas que insistem em simplificar a dimensão estética e artística da pontencialidade do corpo. Contudo, Gauthier (2014), Sodré (2006), Adad (2014), Silva (2008), Castro Jr (2014), entre tantos outros teóricos, nos levam a repensar a dicotomia razão e corpo. Ou seja, a razão do corpo e suas implicações não estão alicerçadas basicamente no cérebro, muito pelo contrário, as bagagens ancestrais (GAUTHIER, 2004; SODRÉ, 1983), as itinerâncias diárias, as intersubjetividades, as alteridades, são tão responsáveis pela suposta razão quanto os princípios biogenéticos.

O corpo que circula pelas cidades, pelas florestas, por qualquer tipo de espaço geográfico, independente da concentração humana, requer elementos tanto do campo biológico quanto dos aspectos culturais. O corpo pode levar consigo todas as experiências com as quais ele cruza/constrói diariamente, e como o corpo é o próprio ser humano, a sua dinamicidade oportuniza mutações subjetivas.

Portanto, o corpo na Sociopoética requer desprendimento individual e participação coletiva para a construção do conhecimento. Para tal, os intercruzamentos corporais são relevantes, pois "os corpos se misturam, fundem-se, tornam-se flexíveis, conseguem escapar da armadura, do lastro organismo-organizado-disciplinado-rígido-submisso e se potencializam, tecendo devires, intensificando a vida, problematizando-a" (ADAD, 2014, p. $50)$.

Nessas articulações, os copesquisadores do PERCURSO foram convidados a derrubar as suas auto armaduras e acionar as indicações do primeiro princípio da Sociopoética que é de se colocar no lugar do outro e depois retornar com outras assimilações. São movimentos necessários para que todos os envolvidos tenham a possibilidade de aprender com a história do outro e refletir sobre as suas subjetividades que, ao sermos sensibilizados, "construímos um novo corpo-pesquisador" (ADAD, 2014, p. 50). Diante do novo corpo-pesquisador, "procuramos não congelar, nem violar, nem vigiar os pesquisados, porque tudo é compartilhado, e nessa partilha de corpos a exploração é infinita, produz-se uma variedade de cores, sons, tons, formas, franzidos, pregas, dobras e contornos" (ADAD, 2014, p. 50-51).

Essa partilha entre os corpos-territórios é de extrema relevância ao passo que permitir a alteridade acentua a necessidade de trazer para a evidenciação as diversas experiências corporais, o campo das possibilidades indetermináveis, já que a Sociopoética e a Razão Cosmopolita ${ }^{\text {vii }}$ não apresentam a necessidade de estabelecer verdade, certezas, concretudes. Revista Interinstitucional Artes de Educar. Rio de Janeiro, V. 7, N. 1 - pág. 467-487 janeiroabril de 2021: "Pedagogias Vitais: Corpo, Desejo e Educação" DOI: 10.12957/riae.2021.54972 
Trabalha-se com ênfase nas possibilidades, os caminhos dos estranhamentos, do pouco ou ainda incompreensível, portanto, imprevisível nas certezas.

Inicialmente informo que aguardava ansiosamente por tal processo formativo, pois me permiti sociopoetizar nas minhas pesquisas e práticas docente, mas com um sentimento de que existiam e existem lacunas para me considerar um ser atravessado de corpo-todo pela filosofia Sociopoética. Então, desde o dia 07 de março de 2018, momento inicial do curso, sinto-me em etapas de rachaduras. Como se o meu corpo estivesse sendo desmontado, desestabilizado e ao mesmo tempo reinventado. Compreendo que tais percepções são fruto, também, da minha disponibilidade em me permitir acessar outras zonas da minha espiritualidade, bem como, pelas provocações verbais, gestuais e principalmente artísticas desenvolvidas pela facilitadora do grupo-pesquisador. (Diário das Trocas de Peles, primeiro semestre de 2018)

Sendo cenário, nessa entrega ao coletivo, o PERCURSO proporcionou aos copesquisadores estabelecer outros significados para o seu próprio corpo-território, posto que uma série de proposições foram articuladas com o intuito de partilhar com os demais as memórias adormecidas/negligenciadas ou intencionalmente soterradas. Portanto, acreditamos que sensibilizar os copesquisadores a ampliar a dimensão das suas afetividades, das suas lembranças, ao passo de perceberem que muito do que eles guardam podem ser potencializados e revertidos em processos criativos e fomentar aulas extremamente significativas para os educandos que futuramente estarão sob a sua mediação.

\section{Pesquisar utilizando técnicas artísticas}

As artes, em geral, têm o poder de provocar estranhamentos, tornar visíveis questões pouco ou quase nunca evidenciadas, e despertar as ignorâncias daqueles que, por diversos motivos, não se aproximaram das temáticas enaltecidas pelas desconstruções artísticas.

Em muitos casos, construímos visões de mundo universais porque o nosso processo educativo e cultural omite uma série de saberes por considerá-los irrelevantes, por não estar dentro da totalidade padronizada pela razão metonímica ${ }^{\text {viii }}$. Já a concepção traçada a partir das artes pretende o oposto, ensinar justamente o que é ignorado e para isso nos instrui "sair por aí transvendo ou estranhando o mundo, (...), abandonar o conhecimento consagrado, instituir o não saber na pesquisa, no ensinar e no aprender para abrir possibilidade do novo" (ADAD, 2014, p. 52). 


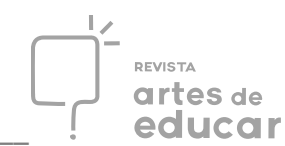

Provocar instabilidades no processo formativo acompanha a incessante prática de questionar as experiências humanas, as verdades que nos são postas como absolutas, bem como as ações de interpelações acerca de todas as vivências. Acrescido a isso, o grupo de copesquisadores deve abusar das oralidades, dos afetos, das trocas com os demais envolvidos no projeto coletivo (Fig. 3). Movimentações consubstanciadas pelos dispositivos artísticos pensados, organizados e propostos pelos articuladores/pesquisadores das oficinas/pesquisa.

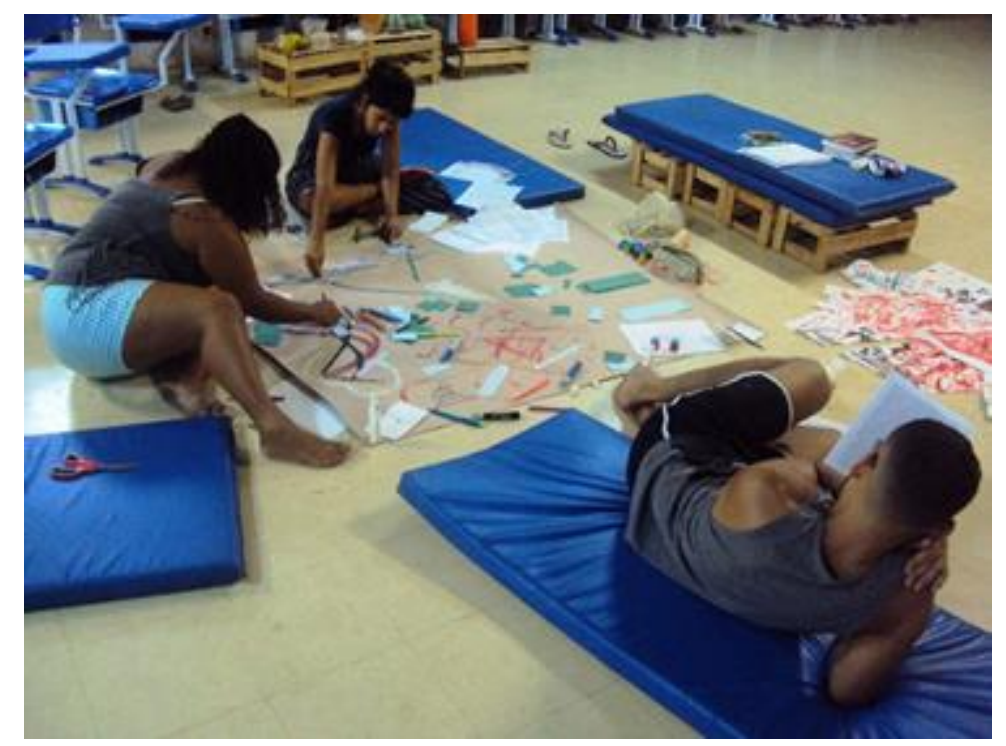

Figura 3: Criação artística durante o PERCURSO. Fonte: Arquivo pessoal, 2018.

Tantos as dificuldades, quantos as habilidades de fácil demonstração foram problematizadas com a finalidade de que cada copesquisador identificasse as suas potencialidades, assim como suas limitações e, a partir disso, avançasse em ambas dicotomias, sobretudo, na perspectiva de "viver uma outra história, criar outros devires, novas singularidades" (GAUTHIER, 1999, p. 54).

\section{A importância da responsabilidade ética, noética e espiritual do grupo-pesquisador no momento do processo de pesquisa.}

Alcançar o quinto princípio requer a mescla dos quatro explicitados anteriormente, posto que uma pesquisa com o corpo todo pode levar o copesquisador a acessar partes das suas ancestralidades que nem ele mesmo sabia da existência e que em muitos casos fogem do 
campo determinável, palpável, visível. Aciona-se a zona da espiritualidade, a qual precisa ser vivida, sentida e dispensa a análise da ciência ocidental.

Admitir a potência das artes é assumir os riscos de instabilizar o tempo linear, as certezas subjetivas ou até mesmo coletivas. Essas ações só são permitidas devido à democracia que perpassa por todo o fazer da Sociopoética, mas acima de tudo, o compromisso dos envolvidos com as culturas de resistências é o que possibilita, sem certezas, a construção de um futuro mais diverso, inclusivo e concentrado (SANTOS, 2002).

Mesclar Conceitos + Afetos nos leva ao termo Confeto $^{\text {ix }}$, ou seja, uma proposta sistematizada pela Sociopoética com a tentativa de criar alternativas educativas prazerosas, com contato humano, vivacidade no olhar, sem medo de se expor e dialogar com os demais.

\section{Confluências propositivas e decoloniais}

Permitir navegar pelos cinco princípios da Sociopoética coloca o corpo-território em um campo diferenciado no que tange a sua constituição, posto que evidencia-se, ao olhar crítico, um cenário de articulações colonizadoras prontas para engessar nossas espiritualidades e nosso afetos. Por isso, visualizamos uma intensa confluência entre a Sociopoética e a abordagem Decolonial. Sobretudo, ao compreender que Sociopoética busca criar Confetos a partir dos grupos subalternizados e que este movimento é enaltecido por ramificações decoloniais.

Por conta dessa confluência, após participar do PERCURSO, decidi que a feitura da minha tese de doutoramento deveria seguir um ineditismo na criação dos dados da pesquisa. Então, optei em Rachar e Despencar os corpos-territórios das copesquisadoras através de um trabalho artístico com ênfase em desenhos e batizei tal perspectiva metodológica de Encruzilhada do Desenho Singular (MIRANDA, 2019).

Desenhar para se comunicar causa em muitas pessoas imenso desconforto e é justamente esta instabilidade que a Encruzilhada do Desenho Singular busca alcançar. A insegurança se estabelece pelo fato de a oralidade ser a primeira possibilidade de comunicação da maior parte das pessoas. Destarte, ter a fala substituída pelo desenho faz com que a pessoa, prontamente, se veja impossibilitada de exercitar o diálogo por não saber desenhar perfeitamente. Tanto que, se não tenho o desenho perfeito, logo estou desprovido da comunicação. Com isso, trabalhamos com o campo da "imaginação, que nos leva a sonhos possíveis e impossíveis" (FREIRE, 2001, p. 71). 


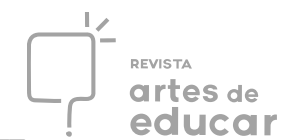

Insisti que os mesmos começassem a pensar em outras formas de comunicação, já que as experiências do dia-a-dia não são produzidas exclusivamente por meios de letras, muito pelo contrário, o fazer diário antecede a leitura das palavras o que está associado com a afirmativa explorada por Paulo Feire (1987): “A leitura do mundo precede a leitura da palavra". O fazer do corpo-território não pode se limitar ao compasso das palavras. Muito antes das palavras, da leitura gráfica, do rebuscar da caligrafia, exercitamos o conhecimento do mundo. Aprisionar o corpo-território às sílabas é limitante para a pluralidade do ato de comunicar, trocar, sentir e afetar por outros sentidos próprios dos seres humanos.

Tenho a sensação de que as práticas pedagógicas enraizadas no positivismo-empirista refutam qualquer indício de partilha das intersubjetividades do corpo-território. Justamente por opor a essa prática desprovida de afetividade e emoções, intento propor o que inicialmente denominei de Hermenêutica do Desenho Singular, mas, ao trilhar outras perspectivas teóricas e experienciais, enxerguei uma vertente epistêmica referenciada nas encruzilhadas afrodescendentes, o que fez imenso diferencial e levou-me a potencializar a Encruzilhada do Desenho Singular.

Ao buscar a origem etimológica da palavra hermenêutica encontramos a ligação com Hermes, um dos deuses grego responsável pela comunicação entre o plano dos mortais e dos imortais. Constatamos intensa familiaridade entre as possibilidades de Hermes com Exu, orixá que também possui a função de realizar o diálogo entre o Òrun e o Àiyéx , ou seja, "cabe a ele levar as oferendas dos humanos aos Orixás" (SOARES, 2008, p. 39). Ainda sobre Exu, encontramos nos escritos do filósofo Soares a afirmativa de que todo ser humano traz consigo as ações do referido Orixá, posto que ele é o responsável pela vida e por toda:

[...] força dinâmica que move o sistema mítico ancestral, como também na vida, no dia-a-dia que, segundo a crença do povo de santo, é a energia que vitaliza as pessoas e de tudo o que existe. Em resumo, sem Exu não tem movimento, $\log$ sem ele não teríamos culto aos orixás, nem vida para os seres.

Se a hermenêutica é "a arte e a ciência da interpretação" (RUNES, 1985), a Encruzilhada de Exu estabelece o papel de compreender as realidades problematizadas pelos centros de produção do saber científico, ao passo de que os princípios interpretativos acionam os valores e saberes africanos e afro-brasileiros, mas que em momento algum deve renegar as contribuições postuladas por tantas outras formas de experiências e cosmovisões, já que sendo Exu o responsável pelas encruzilhadas, significa que os encontros das diferenças é o que potencializa a produção do conhecimento, como podemos evidenciar no mito a seguir: Revista Interinstitucional Artes de Educar. Rio de Janeiro, V. 7, N. 1 - pág. 467-487 janeiroabril de 2021: "Pedagogias Vitais: Corpo, Desejo e Educação" DOI: 10.12957/riae.2021.54972 
Deves ir a dezesseis lugares para saber o que significam / esses cocos de palmeira. / Em cada um desses lugares recolherá dezesseis odus. / Recolherá dezesseis histórias, dezesseis oráculos. / Cada história tem a sua sabedoria, / conselhos que podem ajudar os homens. / Vai juntando os odus / e ao final de um ano terás aprendido o suficiente. / Aprenderás dezesseis vezes dezesseis odus. (PRANDI, 2001, p. 80)

O mito acima nos apresenta um enredo que elucida como Exu se tornou o conhecedor das interculturalidades. Sair por dezesseis territorialidades recolhendo odus ${ }^{x i}$, pode ser compreendido como o compromisso do corpo-território em acessar os mais distintos contextos sociais e apreender, com cada experiência, o arcabouço da alteridade, da diferença, do trato com as particularidades de cada grupo étnico. Portanto, o corpo-território que se permite seguir os ensinamentos de Exu deve criar estratégias para desarticular o epistemicídio calcado e reverberado pela colonização eurocêntrica.

A Encruzilhada do Desenho Singular se coloca em um lugar que acende por rupturas, pois o fato de trazer para dentro da universidade uma pesquisa que evidencia a epistemologia de Exu já provoca inquietações, descrenças. Afinal tem sido natural nos Programas de PósGraduação em Educação, em nível nacional, estudar a infância e ludicidade pelo olhar hermenêutico, currículo da escola pública baiana pela perspectiva hermenêutica, educação especial com veios da hermenêutica, entre outras que naturalmente aparentemente apenas Hermes consegue potencializar. A Encruzilhada do Desenho Singular compreende esta naturalização como espaço de poder e se inscreve como viés responsável por, também, estudar e compreender, analisar a infância e ludicidade, educação especial, currículo, entre demais temáticas que fomente a pesquisa e a complexidade da Educação Brasileira.

Associada a essas questões, a Encruzilhada do Desenho Singular se constitui com ênfase em três perspectivas: Encruzilhada; Desenho; Singular. A primeira se configura como o processo de interpretação de um determinado "real" (SODRÉ, 1988). A categoria Desenho perpassa pelo ato de conceber (imaginário) e representar (material ou imaterial) o processo de comunicação (MIRANDA, 2014). Por sua vez, o Singular está atrelado ao campo das vivências, experiências, da cosmopercepção, que são próprias de cada indivíduo e têm contribuições do coletivo que o circunda (MACHADO, 2013). Ao unir essa tríade caminhamos para a autorização do próprio sujeito em realizar um movimento que exige: 
- Olhar para dentro de si

Este momento é muito importante para a Encruzilhada do Desenho Singular, pois solicita, das pessoas envolvidas na criação dos dados da pesquisa, um processo de consciência corporal, no qual cada um precisa compreender seu corpo como um texto vivo, com muitas páginas, muitas frases borradas, com palavras rasuradas, escritas com tinta forte ou apenas tecidas com lápis de fácil apagamento. É um exercício ético consigo mesmo. De olhar para a sua interioridade, que também é coletiva, percorrer as memórias, desde as mais superficiais às subterrâneas, quase esquecidas.

Olhar para dentro de si não significa realçar o egocentrismo, muito pelo contrário, é ter a oportunidade rara, em um mundo altamente competitivo e acelerado, de desacelerar as demandas do sistema e trabalhar o autocuidado, o cuidado com a sua espiritualidade, com o seu real, com o seu protagonismo, exercitar a sua existência e da sua ancestralidade.

\section{- Escutar o que as suas memórias têm para dizer}

Olhar para dentro de si é um dos grandes desafios que está correlacionado com a autoescuta. A todo tempo, durante as aulas, era notória a dificuldade dos discentes em pautar as suas memórias em associação aos textos teóricos. A sala de aula da graduação parecia ser ocupada por alunos e alunas desprovidos de experiências. Então, a Encruzilhada do Desenho Singular busca romper esse legado do distanciamento da vida dos discentes que existe para além dos portões da universidade. Por isso, trabalhar com o olhar para si e ouvir seu próprio corpo-território é de suma necessidade para uma educação decolonial.

Ouvir nossos próprios afetos e desafetos desestabiliza a racionalidade eurocêntrica de constituição da humanidade. Estamos envoltos em buscar respostas no mundo que nos rodeia, mas muitas das respostas estão fundamentadas nas nossas próprias memórias e que reforçam o nosso direito à fala por, e a partir, das nossas existências.

\section{- Desenhar para viabilizar o processo de comunicação}

Após exercitar o respeito com o seu próprio corpo-território, a Encruzilhada do Desenho Singular alcança um novo desafio: a comunicação através do desenho. Nesse ciclo, existe a possibilidade em expor as compreensões do "olhar para dentro de si" e "ouvir suas próprias memórias". O interessante desse percurso é que muitas pessoas começam a tecer outras formas de se relacionar com o mundo, o que não significa que estão preparadas para compartilhar com os demais as suas afetações. Portanto, recorrer ao desenho como 


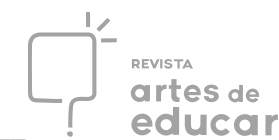

instrumento de comunicação, além do que já foi dito anteriormente, leva a pessoa a exercitar com maior ênfase o que seus traços no papel querem revelar. Na sala de aula, os desenhos compartilhados entre os discentes gerava uma série de novas inquietações. Neste caso, cabia ao responsável pelo desenho utilizar a oralidade para trazer novas informações e se fazer compreensível aos colegas. Neste cenário, o desenho recebe o auxílio da oralidade para intensificar a comunicação.

Ainda sobre a questão Singular, recorremos a filósofa Oyèrónkẹ Oyěwùmí (2017) que nos apresenta uma perspectiva de corpo iorubano onde a visão não assume a hierarquia dos sentidos. Para os povos iorubás, existe uma mescla entre os sentidos do corpo, já a sociedade ocidental exercita com maior ênfase a visão por estabelecer que a leitura do corpo do outro é o primeiro ponto de percepção, comunicação e que leva a exclusão:

O termo "cosmopercepção" é uma maneira mais inclusiva de descrever a concepção de mundo por diferentes grupos culturais. Neste estudo, portanto, "cosmovisão" só será aplicada para descrever o sentido cultural ocidental e "cosmopercepção" será usada ao descrever os povos iorubás ou outras culturas que podem privilegiar sentidos que não sejam o visual ou, até mesmo, uma combinação de sentidos. (OYĚWÙMÍ, 2017, p. 3)

Portanto, a Encruzilhada do Desenho Singular convida o corpo-território a caminhar por dentro das suas próprias lembranças, escutar as narrativas que compõem a sua corporeidade, exercitar os seus sentidos para além da visão e em seguida desenhar elementos que elucidem a comunicação. Então, se Exu na epistemologia afro-brasileira representa a comunicação e se cada um de nós somos atravessados pela dinamicidade de Exu, por conseguinte, todo ato de comunicação humana só se concretiza pela permissão de Exu, posto que as encruzilhadas, o local de morada deste Orixá, é o ponto de passagem, de fruições, de caminhos para todo e qualquer ato de comunicação.

Nesse bojo, construo articulações entre as contribuições de Sodré (1988) com as proposições da Encruzilhada do Desenho Singular. Se Exu é diversidade e transita por todos os espaços e se o trânsito é permitido por ele, com isso, a universidade não pode se pautar por um único viés epistemológico.

A Encruzilhada do Desenho Singular se configura como uma outra opção de evidenciar que o estudo sobre culturas geralmente legitima a universalização das diferenças, o que ratifica padrões de signos e símbolos na produção e reprodução social. Nesse âmbito, optamos em expandir o campo conceitual para compreender a intersubjetividade do outro, para isso deve-se levar em conta que "cultura é o modelo de relacionamento humano com seu 
real. Este 'real' não deve ser entendido como a estrutura histórica globalmente considerada nem mesmo como um conjunto de elementos identificáveis" (SODRÉ, 1988, p. 48). O real aqui apresentado contrapõe o universal, ou seja, abarca a singularidade e faz com que outros indivíduos, a partir do convívio, da escuta, das observações e, sobretudo das alteridades, compreendam o que é simbolicamente relevante para os grupos de corpo vivo que pretendem tecer compreensões.

Nesse interim, a perspectiva da Encruzilhada do Desenho Singular adota o pressuposto de que é necessário extrapolar o campo das aparências (SODRÉ, 1988), já que no Ocidente a palavra aparência passou a ser empregada com cunho pejorativo e universalizante, pois proporciona um antagonismo entre o real e o irreal.

Sendo assim, o aparente, o visível não necessariamente representa a totalidade de quem constrói o seu real, a sua cultura, ou seja, o aparente é irrisório para a compreender o corpo-território. Evidenciar a potência do desenho como dispositivo de pesquisa é trazer para o campo das supostas certezas a veridicidade das dualidades, posto que o próprio desenho grafado pelo sujeito proporciona uma infinidade de leituras/interpretações para quem está do outro lado. Contudo, o movimento de pôr na centralidade o responsável pelos traços desenhísticos significa alimentar a esfera que externa as intersubjetividades e caminha para o processo da comunicação, em que as aparências podem ou não ser reafirmadas, ressignificadas, desconstruídas.

\section{(In)conclusões porque ainda temos muito que rachar e despencar}

Quando propus a escrita deste texto intentei dialogar com as prováveis leitoras e leitores sobre a importância de questionar o nosso corpo-território ao assumir a condição de pesquisador(a). Sempre tive ojeriza à ideia de que o corpo que pesquisa precisa ser neutro, frio, distante do objeto em estudo, demarcado apenas pela análise e interpretação do que se pretende verificar e devolver à universidade um cumulado de páginas do Word em formato de ciência.

Chego ao doutoramento em Educação com a provocação de sentir, de corpo todo, como uma metodologia, a ser utilizada para fecundar os passos de uma tese, traria para a vida de um pesquisador ressignificações, não somente à problemática de pesquisa, mas na vida de quem dedica 48 meses em compreender um fenômeno social. Justamente nessa relação de disputas, nesse jogo de saberes, a Sociopoética aparece na tessitura da escrita da tese. Revista Interinstitucional Artes de Educar. Rio de Janeiro, V. 7, N. 1 - pág. 467-487 janeiroabril de 2021: "Pedagogias Vitais: Corpo, Desejo e Educação" DOI: 10.12957/riae.2021.54972 
Ao ler sobre este dispositivo filosófico de pesquisa, ser convidado e tensionar a feitura do meu próprio corpo-território, sentir que sou um texto vivo, um corpo-texto, uma bússola da minha existência e que muito do que acredito se pauta em uma perspectiva colonizadora, por si só, já desarticula a falácia que garante a intrínseca separação e a universal parcialidade científica.

Com isso, aponto que a Sociopoética tem seus rigores, seus critérios e a análise dos dados com características próprias para um fazer ciência. Contudo, é inquestionável que quem escolhe transitar por este caminho, mesmo na condição de pesquisador(a)/facilitador(a), (in)conclui por vias múltiplas que o nosso corpo-território reverbera ao encontrar outros corpos-territórios atravessamentos que levam ao Rachar e Despencar.

Se não fossem as rachaduras e os despencamentos oportunizados pela Sociopoética, provavelmente teria ressiginificado meu corpo-território por outras trocas sensíveis e que não me autorizo a supor nestas linhas, pois prefiro escrever a partir do que me desconsertou, como elucido em um diário elaborado durante o PERCURSO:

\begin{abstract}
Ainda estamos no devir formativo do curso de Sociopoética facilitado pela sensível e humana professora Shara Adad. E nesse percurso fui convidado a escrever o que tem me afetado nos últimos dois dias. Inicialmente informo que aguardava ansiosamente por tal processo formativo, pois me permiti sociopoetizar nas minhas pesquisas e práticas docente, mas com um sentimento de que existiam e existem lacunas para me considerar um ser atravessado de corpo-todo pela filosofia Sociopoética. Então, desde o dia 07 de março de 2018, momento inicial do curso, sinto-me em etapas de rachaduras. Como se o meu corpo estivesse sendo desmontado, desestabilizado e ao mesmo tempo reinventado. Compreendo que tais percepções são fruto, também, da minha disponibilidade em me permitir acessar outras zonas da minha espiritualidade, bem como, pelas provocações verbais, gestuais e principalmente artísticas desenvolvidas pela facilitadora do grupo-pesquisador. (Fonte: diário de trocas de peles, 2018).
\end{abstract}

Voltar ao diário, batizado como Trocas de Peles, traz um misto de receio/medo com uma fagulha de alívio. Falo do alívio como um ponto de conforto perante uma trajetória contra colonial de constantes conflitos. Por mais que a Sociopoética não tenha sido criada dentro das abordagens decoloniais, ela consegue nos abastecer com repertórios acadêmicos insurgentes, desobedientes e, ao mesmo tempo, palatáveis pela ciência, já que consegue através de outras vias, entregar um fazer pesquisa que reivindica sua validade contra hegemônica.

Ainda sobre o diário, afirmei a presença do receio/medo como um dos sentimentos suscitados nas minhas memórias. Corpo-território que busca transitar pela decolonialidade Revista Interinstitucional Artes de Educar. Rio de Janeiro, V. 7, N. 1 - pág. 467-487 janeiroabril de 2021: "Pedagogias Vitais: Corpo, Desejo e Educação" DOI: 10.12957/riae.2021.54972 


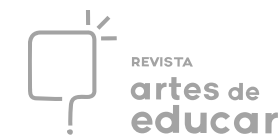

sempre se depara com o medo, o que não pode ser convertido em paralisia. Mas, como pedir ao corpo-território, que tanto sofre violência, não se permitir paralisar? Como pedir ao corpoterritório negro, indígena, LGBT+, que olhe para a escola e sinta afetos e desejos de ocupar o chão da sala de aula? Como tornar a educação como um território saudável para o corposubalternizado?

Vou me despedindo, temporariamente, com vontade de dialogar muito mais com você. Percebo a potência em socializar que é possível pesquisar na universidade por caminhos que fissuram a neutralidade imposta como a única possibilidade para legitimar a tessitura de uma escrita. Dialogar com você, mesmo que por aqui, significa, para o que acredito, o fortalecimento de uma rede de pessoas dispostas a nutrir uma outra linha metodológica no fazer academia. Somos muitos e muitas espalhados por várias partes do nosso país, da América Latina e demais espacialidades contra-coloniais. Sigamos rompendo, mas também propondo outros caminhos, outros fazeres, outras vias para rachar e despencar nosso corpoterritório.

\section{REFERENCIAS}

ADAD, Shara Jane. H. Costa. A Sociopoética e os cinco princípios: a filosofia dos corpos misturados na pesquisa em educação. In: S. H. C. Adad; S. H. Petit; I. Santos; J. Gauthier. (Org.). Tudo que não inventamos é falso: dispositivos artísticos para pesquisar, aprender e ensinar com a sociopoética. 1ed. Fortaleza - CE: Editora da Universidade Estadual do Ceará EdUECE, 2014.

ADAD, Shara Jane. H. Costa. Pesquisar como o corpo todo: multiplicidades em fusão. In: SANTOS, I. dos. et al. (Org.). Prática da pesquisa nas ciências humanas e sociais: abordagem sociopoética. São Paulo: Editora Atheneu, 2005. p. 217-237.

FREIRE, P. Professora sim, tia não: cartas a quem ousa ensinar. São Paulo: Olho dágua, 2001.

GAUTHIER, Jacques. Sociopoética: Encontro entre arte, ciência e democracia na pesquisa em ciências humanas e sociais, enfermagem e educação. Rio de Janeiro: EAN/UFRJ, 1999.

GAUTHIER, Jacques. Trilhando a vertente filosófica da montanha: Sociopoética - a criação coletiva de confetos. In: SANTOS, Iraci dos; GAUTHIER, Jacques; PETIT, Sandra Haydée (Org.). Prática da Pesquisa nas ciências humanas e sociais: abordagem sociopoética. 1. ed. São Paulo: Atheneu, 2005, p. 257-286.

GONZALEZ, Lélia. A categoria político-cultural de amefricanidade. In: Revista Tempo Brasileiro, Rio de Janeiro, n. 92/93, p. 69-82, jan./jun, 1988. Disponível em: Revista Interinstitucional Artes de Educar. Rio de Janeiro, V. 7, N. 1 - pág. 467-487 janeiroabril de 2021: "Pedagogias Vitais: Corpo, Desejo e Educação" DOI: 10.12957/riae.2021.54972 
$<$ https://negrasoulblog.files.wordpress.com/2016/04/a-categoria-polc3adtico-cultural-deamefricanidade-lelia-gonzales1.pdf > Acesso em: 30 set. 2020.

LUZ, Narcimária Correia do Patrocínio. Abebe: a criação de novos valores na educação. Salvador: SECNEB, 2000.

MACHADO, Vanda. Mitos afro-brasileiros e vivências educacionais. Salvador: EDUFBASMEC, 2002.

MIRANDA, Eduardo Oliveira. Trocas de peles no Atiba-Geo: proposições decoloniais e afro-brasileiras na invenção do corpo-território docente. 2019. $157 \mathrm{f}$. Tese (Doutorado em Educação) - Faculdade de Educação, Universidade Federal da Bahia, Salvador, 2019. Disponível em: <https://repositorio.ufba.br/ri/bitstream/ri/29509/1/Eduardo\%20Miranda\%20\%20Tese.pdf>. Acesso em: 18 set. 2020.

MIRANDA, Eduardo O. "O negro do Pomba quando sai da Rua Nova, ele traz na cinta uma cobra coral": os desenhos dos corpos-territórios evidenciados pelo Afoxé Pomba de Malê. 2014. 180 f. Dissertação (Mestrado Acadêmico em Desenho Cultura e Interatividade) Universidade Estadual de Feira de Santana, Feira de Santana, 2014. Disponível em: <http://tede2.uefs.br:8080/bitstream/tede/97/2/Disserta\%C3\%A7\%C3\%A3o\%20de\%20Eduar do\%200\%20MIranda.pdf $>$. Acesso em 30 set. 2020.

OYĚWÙMÍ, Oyèrónkẹ́ . Visualizing the Body: Western Theories and African Subjects in: OYĚWÙMÍ, Oyèrónkẹ . The invention of women: making an African sense of western gender discourses. Minneapolis: University of Minnesota Press, 1997, p. 1-30. Tradução para uso didático de Wanderson Flor do Nascimento. Disponível em: <https://filosofiaafricana.weebly.com/uploads/1/3/2/1/13213792/oy\%C3\%A8r\%C3\%B3nk\%E1\%BA\%B9\%C C\%81_oy\%C4\%9Bw\%C3\%B9m\%C3\%AD_-_visualizando_o_corpo.pdf?fbclid=IwAR3CvhvpNQBEi9M3y-R2q6I87bupkTWpCYH9xlt9pXoAAck6MWh-WAhDPc> Acesso em: 23 set. 2020.

Runes DD (ed.). Diccionario de Filosofía. Ed. Grijalbo, Barcelona, 1985.

SANTOS, Boaventura de Sousa. Para uma sociologia das ausências e uma sociologia das emergências. Revista Crítica de Ciências Sociais, 63, outubro/2002. Disponível em: $<$ https://journals.openedition.org/rccs/1285> Acesso em: 10 set. 2020.

SOARES, Emanoel Luís Roque. As vinte e uma faces de Exu na filosofia afrodescendente da educação: imagens, discursos e narrativas. 2008. Tese(Doutorado em Educação) Universidade Federal do Ceará, Fortaleza, 2008.

SODRÉ, Muniz. O terreiro e a cidade: a forma social negro-brasileira. Petrópolis: Vozes, 1988.

SODRÉ, Muniz. A verdade seduzida. Rio de Janeiro: Francisco Alves, 1983.

\footnotetext{
${ }^{\text {i }}$ Docente do Departamento de Educação da Universidade Estadual de Feira de Santana - UEFS. Doutor em Educação pela UFBA. Professor do Mestrado em Educação - PPGE/UEFS. Coordenador do Grupo de Pesquisa 
Corpo-território, Educação e Decolonialidade. Feira de Santana/BA - Brasil. ORCID iD: https://orcid.org/0000$\underline{0001-5836-4761}$

ii ESCOLA SEM PARTIDO. Anteprojeto de lei municipal e minuta de justificativa. Disponível em: <http://www.programaescolasempartido.org/municipal>. Acesso em: 28 setembro 2020.

iiiPara maiores problematizações, sugiro a leitura: Junqueira, R. D. (2018) A invenção da "ideologia de gênero": a emergência de um cenário políticodiscursivo e a elaboração de uma retórica reacionária antigênero. Psicologia Política, 18(43), p. 449-502.

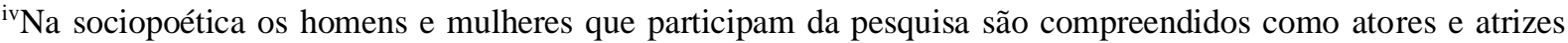
ativos na criação dos elementos da pesquisa. Por isso, não são chamados de "sujeitos da pesquisa", mas sim de copesquisadores e copesquisadoras que assumem em parceria com o pesquisador facilitador as responsabilidades por todas as etapas.

${ }^{\mathrm{V}}$ Ao longo do texto utilizaremos memórias advindas do diário referente ao PERCURSO.

vi“ A razão proléptica, que não se aplica a pensar o futuro, porque julga que sabe tudo a respeito dele e o concebe como uma superação linear, automática e infinita do presente" (SANTOS, 2002, p. 40).

vii“"A razão cosmopolita prefira imaginar o mundo melhor a partir do presente. Por isso propõe a dilatação do presente e a contraç̧ão do futuro. Aumentando o campo das experiências, é possível avaliar melhor as alternativas que são hoje possiveis e disponiveis" (SANTOS, 2002, p. 274).

viiii"A razão metonímica, que se reivindica como a única forma de racionalidade e, por conseguinte, não se aplica a descobrir outros tipos de racionalidade ou, se o faz, fá-lo apenas para as tornar em matéria-prima" (SANTOS, 2002, p. 40).

${ }^{\text {ix} O s ~ c o n f e t o s ~ s a ̃ o ~ m a i s ~ d o ~ q u e ~ e n u n c i a d o s ~ i n t e l e c t u a i s, ~ s a ̃ o ~ a ~ e x p r e s s a ̃ o ~ d e ~ e x p e r i e ̂ n c i a s ~ c o l e t i v a s ~ q u e ~ i m p l i c a m ~ o ~}$ corpo sensível, portanto, uma forma potente de pensamento que não se limita à razão. Os conceitos, portanto, podem ser poéticos e/ou metafóricos, miscigenados, interferênciais. Geralmente, anarquizam referências prévias. (PETIT; ADAD, 2009, p. 5).

" $O$ àiyè é o universo físico concreto, e a vida de todos os seres naturais que o habitam, portanto, mais precisamente, os arà-àiyè, ou aràiyè, são os habitantes do mundo, a humanidade. Já o òrun corresponde ao espaço sobrenatural, o outro mundo, o além, algo imenso e infinito. Nele habitam os arà-òrun, que são os seres ou entidades sobrenaturais" (LUZ, 2000, p.109).

${ }^{x i}$ Expressão típica do culto Ifá que foi incorporada aos Candomblés do Brasil. Seu significado remete a destino, caminhos, possibilidades. 